\title{
THE EUROPEAN UNION AND THE WORLD TRADE ORGANIZATION: PROBLEMS AND CHALLENGES
}

\begin{abstract}
Julija Brsakoska Bazerkoska*
Summary: This article gives an insight into the most essential issues of EC/EU membership in the WTO. After briefly explaining the main functions of the GATT and the WTO, the author gives an overview of the EC/EU role in the GATT/WTO. The article outlines the major challenges that both the EU and WTO face today. It argues that many of the changes within the EU have been influenced by its membership of the WTO. Finally, the article summarises the status of GATT and WTO agreements in EU law.
\end{abstract}

\section{Introduction}

After the Second World War, the General Agreement on Tariffs and Trade (GATT) was established in 1947 as part of the Bretton Woods system. The main intention was to give the new world order an economic foundation, based on the theory of comparative advantage and free trade. ${ }^{1}$ From January 1995 , the GATT was replaced by the World Trade Organization established with the Marrakesh Agreement. The main functions of the WTO under the Agreement are outlined below.

First, the WTO oversees the operation of the WTO agreements on international trade. WTO agreements include: the General Agreement on Tariffs and Trade (GATT) together with twelve related agreements on trade in goods in the area of agriculture, textiles and clothing, dumping, subsidies and countervailing measures, sanitary and phytosanitary measures, technical barriers to trade, trade-related investment measures, safeguards, customs valuation, import licensing, rules of origin and pre-shipment inspection, the General Agreement on Trade in Services (GATS), and the Agreement on Trade Related Aspects of Intellectual Property (TRIPS Agreement).

The WTO also serves as a forum for trade negotiations, trying to expand trade in goods and services in accordance with the principle of sustainable development and environmental protection.

\footnotetext{
Teaching assistant at the Faculty of Law in Skopje, Republic of Macedonia. Doctoral candidate at Cologne University, Faculty of Law, Germany.

1 Gerhard Pischel, 'Trade, Treaties and Treason: Some Underlying Aspects of the Difficult Relationship between the EU and the WTO' (2001) 6(1) European Foreign Affairs Review 103, 105.
} 
The third function assigned to the WTO under the Marrakesh Agreement is the dispute settlement system. Dispute settlement is the central pillar of the multilateral trading system and makes the trading system more secure and predictable. For this reason, the creation of the WTO has very often been identified with the establishment of a system for the adjudicative resolution of disputes. Some authors even argue that the effectiveness and sophistication of the dispute settlement system surpasses what has been achieved by other international tribunals, such as the International Court of Justice. ${ }^{2}$ The dispute settlement mechanism within the WTO is among the most highly legalised ones in the existing framework of international agreements. ${ }^{3}$ Under the WTO, the member countries that are parties to various treaties under the WTO umbrella have access to dispute settlement as a right. This means that, unlike under the original GATT, the consensus of the member countries for the dispute settlement ruling to become binding is no longer needed. So-called 'negative consensus' exists under the WTO. This means that the dispute settlement ruling will not be binding only if all members, including the winning party, vote against its implementation. In all other cases, the ruling will be adopted as binding. In addition, it is determined when and how the losing party must act in order to implement the dispute settlement ruling, or otherwise the party can become a subject to arbitration. In cases where the losing party does not implement the ruling in accordance with the findings of the arbitration, retaliation ${ }^{4}$ is automatically authorised. Additionally, the legal decision of the first-instance panel may be appealed to the Appellate Body. The Appellate Body is composed of seven jurists, three of whom sit on each case. ${ }^{5}$ These are all fundamental changes to how the GATT system operated.

The establishment of the WTO caused major shifts in the issues that were previously dealt with by the GATT. The focus on tariff barriers was shifted towards issues connected to trade-related investment measures, trade in services and trade related aspects of intellectual property.

The fact that Europe is the biggest trader in the world, responsible for roughly a fifth of the global trade in goods and services, marks the relationship between the EU and the World Trade Organization as one

\footnotetext{
2 See Robert Howse, 'Adjudicative Legitimacy and Treaty Interpretation in International Trade Law: The Early Years of WTO Jurisprudence' in JHH Weiler (ed), The EU, WTO and NAFTA: Towards a Common Law of International Trade? (OUP 2000) 35.

3 Billiet, 'From GATT to the WTO: The Internal Struggle for External Competencies in the EU' (2006) 44(5) JCMS 899, 901.

4 The trade concessions that the winning party gives to the losing party will be withdrawn.

$5 \quad$ For more on the procedures for dispute settlement in the WTO, see 'Understanding on Rules and Procedures Governing the Settlement of Disputes' (WTO 2011) http://www.wto. org/english/docs_e/legal_e/28-dsu_e.htm accessed 25 May 2011.
} 
of the cornerstones of contemporary global governance. ${ }^{6}$ The previously mentioned changes implemented with the establishment of the WTO, the strengthening of the institutional framework of the WTO, and the increase of the scope of the organisation have had an important impact on the balance of power within the EU with regard to trade policy. ${ }^{7}$ For these reasons, both the status of the EU in the WTO and the status of the WTO in the EU will be examined.

\section{The status of the EC in the GATT}

The GATT promoted trade liberalisation on the basis of non-discrimination, transparency and reciprocity. However, the GATT also defined a number of important exceptions to these principles, such as: continued use of tariffs, import quotas, anti-dumping duties, and subsidies. One of these exceptions concerned free trade areas and customs unions. ${ }^{8}$ Therefore, some authors argue that the GATT enabled the establishment of the EC in the first place. ${ }^{9}$ However, with the exception of free trade areas and customs unions, the GATT gave the EC an opportunity to play an important role within its system.

The European Community was not a contracting party to GATT 1947. Only the EC Member States were. However, over the years, the EC acquired the status of a contracting party for all purposes. ${ }^{10}$ All trade agreements and protocols negotiated in the GATT framework provided in their final provisions that the agreements were open for acceptance by the 'contracting parties to the GATT and by the EEC (or EC)'. ${ }^{11}$ Since 1970, most agreements negotiated in the GATT framework have been accepted only by the EC, ie without separate acceptance by the EC Member States. ${ }^{12}$

Starting with the Treaty of Rome in 1957, the internal tariff walls within Europe were gradually taken down. The Member States of the European Communities established a common set of tariffs towards the rest of the world, while the duties on internal trade were dismantled in 1968 . According to article 133 TEC, the EC had the authority to manage the common tariff wall. Therefore, the EC was acting as a contracting party

\footnotetext{
6 JL Mortensen, 'The World Trade Organization and the European Union' in KE Jorgensen (ed), The European Union and International Organisations (Routledge 2009) 80.

7 See Billiet (n 3) 899.

8 GATT article XXVI.

$9 \quad$ See as an example Mortensen (n 6) 83.

10 Jacques HJ Bourgeois, The European Court of Justice and the WTO: Problems and Challenges' in Weiler (n 2) 71.

${ }_{11}$ See as an example article VI (1) in the International Bovine Meat Agreement; art 9.1.1 in the Agreement on Trade in Civil Aircraft.

12 See Bourgeois (n 10) and Jacques HJ Bourgeois, 'The Tokyo Round Agreements on Technical Barriers and on Government Procurement' (1982) 19 CML Rev 5.
} 
under GATT and had effectively replaced its Member States as bearers of rights and obligations. This could only have been done with the consent of the other GATT contracting parties. Since 1960, all GATT contracting parties have accepted that the EC exercised practically all the rights and fulfilled all the obligations under GATT law as a GATT contracting party. ${ }^{13}$

Another interesting aspect of the relationship between the EC and the GATT is the gradually changing role of the EC within different rounds of GATT negotiations. Mortensen identifies the EC as a defensive GATT player at the beginning of the GATT's existence. According to him, external circumstances permitted internal factors to shape EC behaviour in the early GATT years, allowing domestic priorities to dominate trade diplomacy. He defines this behaviour as a defensive version of European neo-mercantilism, and claims that this was more or less tolerated by the US, although concrete trade conflicts were fought bilaterally and occasionally inside the GATT. ${ }^{14}$ However, none of these conflicts caused fundamental problems. The main issue on which the EC was attacked in Washington and Geneva was its Common Agricultural Policy (CAP). This was the case because US farmers felt the effects of the CAP in falling world market prices. During the 1960s, both the European Member States and industry representatives fended off US demands for market liberalisation. Therefore, the Kennedy Round (1964-1969) was perceived as a consolidation of the EC as a defensive GATT player.

It was only the Tokyo Round (1973-1979) that set GATT in motion after the standstill of the 1960s. However, it failed to produce new GATT rules on new forms of protectionism, namely the non-tariff barriers. ${ }^{15}$ Nevertheless, during the Uruguay Round, GATT diplomacy changed greatly. Fourteen negotiation groups were formed to conclude agreements on issues like agriculture, intellectual property rights, and services, as well as institutional reforms. ${ }^{16}$ Besides the fact that the deadline established for the Uruguay Round was not met, and that there were major disagreements on issues connected with agriculture, this was a significant stage for both the EC and the GATT. EC diplomats played a leading role in all other areas of the Round. After certain hesitations, the EC joined forces with the Americans on the GATS and TRIPS issues, and endorsed US ideas on the inclusion of services and on intellectual property rights. ${ }^{17}$ Agriculture may have caused many difficulties, but the breakthroughs on the GATS, TRIPS and dispute settlement reforms proved to be more

\footnotetext{
13 See,Bourgeois (n 10) 72; Mortensen (n 6) 83-86.

14 Mortensen (n 6) 83-86.

15 ibid.

16 ibid.

17 R Leal-Arcas, 'The Resumption of the Doha Round and the Future of Services Trade' 29 Loyola of Los Angeles International and Comparative Law Review 339.
} 
significant. Both agreements protect current European competitiveness in designer goods, pharmaceuticals and the global service industries. ${ }^{18}$

\section{The Status of the EU in the WTO}

The EC became an original member of the WTO in 1994. Due to its extensive and exclusive competences on trade policy issues, membership came as a continuation of the practice of the EC's de facto membership in the GATT. As the Member States have competences in some WTO issues, they are also WTO members. Article XI of the Marrakesh Agreement that established the WTO states that the contracting parties to GATT 1947, including all of the EC Member States and the European Communities, would become original members of the WTO. However, there is no requirement for a declaration of competence. With regard to voting, each WTO member has one vote, while the EC has a number of votes equal to the number of its Member States that are WTO members. It is also stipulated that the number of votes of the EC and its Member States shall not exceed the number of the Member States. ${ }^{19}$ In practice, voting is rarely used in WTO decision making.

Furthermore, after the conclusion of the Uruguay Round, the EC Council, the Commission, and the Member States agreed on a 'code of conduct' for future WTO negotiations. ${ }^{20}$ The ECJ emphasised the duty of the Community and the Member States to cooperate in the work of the WTO in Opinion 1/94 Competence of the Community to conclude international agreements concerning services and the protection of intellectual property-article 228 (6) EC Treaty. ${ }^{21}$ However, the ECJ did not further elaborate the consequences of that duty. The EC Commission, the Council, and the Member States subsequently entered into negotiations over a general code of conduct for the participation of the EC and its Member States in the WTO, but the negotiations were never concluded. The matter became part of the 1996 Intergovernmental Conference leading to the Amsterdam Treaty, which only managed to achieve a limited modification of article 133 EC Treaty. At present, there is still no general document on EU and Member States participation in the WTO. ${ }^{22}$

Nevertheless, there seemed to be no major difficulties in practice arising from this joint membership and the Community was the main

\footnotetext{
18 Mortensen (n 6) 83-86.

19 Art IX Marrakesh Agreement establishing the WTO.

20 Rachel Frid de Vries, 'European Community, Membership in International Organizations or Institutions', The Max Planck Encyclopedia of Public International Law (OUP 2009 online edition) <www.mpepil.com> accessed 24 May 2010.

21 ECJ, Opinion 1/94 (WTO Agreements) [1994] ECR I-5267.

22 Frid de Vries (n 20).
} 
actor. ${ }^{23}$ There are a number of factors that explain the success of this joint membership which in effect comes close to exclusive Community/ Union membership. Perhaps the most important one is that legal, economic, and diplomatic expertise in trade issues is generally located in the European Commission. Therefore, there is no real difference in how disputes that concern mixed competences and those concerning exclusive competences are dealt with. In both cases, Commission officials are the primary actors. ${ }^{24}$

After the Treaty of Lisbon came into force, the EC was replaced by the European Union as a member of the WTO. The powers within the Common Commercial Policy of the Union are delegated from the national to the supranational level on all matters concerning international trade. Accordingly, the European Commission speaks for the Union in the WTO and acts like all other foreign policy actors in the WTO. It is common practice to let the EU representative speak on behalf of all Member States in the WTO. This is the case even if individual Member States are present. Furthermore, with regard to WTO dispute settlement, the legal service of the Commission is the one that takes up the defence in cases brought against EU Member States.

It is the European Commission that negotiates at the World Trade Organization on behalf of the EU. The Commission coordinates with the EU Member States through the Trade Policy Committee (article 133 Committee $)^{25}$ and conducts EU policy following the guidelines set down by the Member States in the Council of Ministers. The Commission also

\footnotetext{
${ }^{23}$ See Frid de Vries (n 20); Mortensen (n 6) 83-87.

24 See the research on the experiences of DG trade officials and officials from the Commission's legal service dealing with WTO disputes in Billiet (n 3) 906.

25 Article 133 Committee was provided in article 133 TEC. This is a Council committee chaired by the Council Presidency and consists of high-level Member State civil servants in the EU Council of Ministers in Brussels. It is responsible for assisting the Commission in negotiations on trade and tariff matters which the latter conducts on behalf of the Community. It has a key role in ensuring that the Council accepts the final results of negotiations, and therefore in the formation of unity. From a formal view point, it is the Council Presidency that leads the negotiations in article 133 Committee, but de facto and from a substantial point of view it is the Commission that leads the negotiations to find a common position in trade matters. From a procedural view point, article 133 Committee is not a voting committee, just a consultative body. In order to have close cooperation between the national and the European levels on issues of exclusive and mixed competence, there are continuous informal negotiations between article 133 Committee and the Commission. For example, in the case of trade in services, there are bilateral or multilateral negotiations every two weeks. The Commission tries to follow the decision of the majority in these negotiations. However, when there is no convergence between national and supranational interests, the Commission may impose its position. Different commercial issues are discussed in article 133 Committee before being sent to the WTO for negotiation. Since most issues are, therefore, treated in article 133 Committee, in principle there is no need to go to the political level (COREPER or General Affairs Council) to solve problems, unless no consensus is found at the technical level.
} 
regularly informs the European Parliament of key WTO issues. When an agreement is negotiated at the WTO, the Commission needs the formal authorisation of the Council and European Parliament to sign the agreement on behalf of the EU. All agreements must be ratified by the Council of Ministers by a qualified majority. Under the Lisbon Treaty, the role of the Parliament in the process of concluding international agreements has been strengthened and the consent of the EP is needed before the conclusion of treaties. ${ }^{26}$ Therefore, according to this procedure of the Geneva negotiations, it can be seen that the diplomatic machinery of the EU within the WTO is rather complex. Namely, the relevant European Parliament Committees, like those on International Trade or Development, are considered to be part of the permanent apparatus of EU trade diplomacy. At the centre of EU diplomacy at the WTO is the DG External Trade unit in the Commission. DG Trade consists of roughly 550 people, currently headed by Commissioner Karel De Gucht. ${ }^{27}$ Furthermore, Article 133 Committee is also part of the core diplomatic machinery. The 'EU representation to International Organizations in Geneva' is another part of trade diplomacy even if it also manages relations with other Genevabased international organisations. Finally, the national representation of the Member States in Geneva should be added to this list. Therefore, the conclusion is that the power of EU trade bureaucracy in daily WTO matters is significant. The governance of the WTO, which is mostly issuespecific, requires extensive legal and diplomatic expertise. This places the Commission at the centre of most everyday activities in the WTO.

Most of the criticism on EU representation in the WTO, particularly in the United States, goes to the double weight of votes. Since both the European Union and its Member States are formally represented in the WTO process, it is argued that EU interests have double weight in the WTO. Nevertheless, article IX of the WTO Agreement determines that the number of votes cannot exceed the number of the individual European Community (EC) Member States. Moreover, the WTO Councils and bodies operate on a consensus voting norm and thus WTO issues are almost never put to a formal vote. Consensus is determined in the corridors and not by counting votes at meetings. ${ }^{28}$

According to Bourgeois, anomalous dual membership may prove to be a bad solution, especially for the EC/EU and from the Member States' perspective. Under GATT 1947, the other contracting parties had pragmatically accepted the EC as a single entity on the grounds that one should not open Pandora's Box in reviewing the GATT in order to formally

\footnotetext{
26 Article 218 TFEU.

27 'Organisation' (European Commission: Trade 2011) <http:/ /ec.europa.eu/trade/about/ organisation/index_en.htm> accessed 1 June 2011.

28 Mortensen (n 6) 82.
} 
substitute the EC for its Member States. Article XI of the WTO Agreement caries the risk that these efforts will come to naught. ${ }^{29}$

After the establishment of the WTO, according to Mortensen, the European Union took over leadership in the negotiation process. The EU put forward a new agenda, the so-called 'trade and ... agenda'. ${ }^{30}$ Under the leadership of the EU, labour standards, exceptions for better environmental protection, procurement liberalisation and global competition rules were put on the agenda. However, the rest of the WTO was hostile, especially to issues like social rights and the environment. The developing world had little confidence in the EU. To them, this looked more like 'neo-colonialism and green protectionism than free and fair world trade'. ${ }^{31}$

In 2001, the EU was the main instigator of the Doha Development Agenda. After eight rounds of trade negotiations initiated by the United States, the ninth one in Doha was initiated by the EU after five years (1996-2001) of campaigning. According to Anders Ahnlid, the EU met with a fair degree of success in its quest for a new round, despite the persistent protectionist nature of the Common Agricultural Policy and the new demands emanating from civil society on trade policy in areas such as the environment, labour rights and global justice. He argues that the ability of the European Commission to form appropriate strategies depends on EU willingness and its ability to exert leadership. A successful strategy has to strike a balance between what is needed to satisfy EU Member States domestically, on the one hand, and what is feasible at the multilateral level, on the other hand. ${ }^{32}$

The process of strengthening the institutional framework of the dispute settlement system within the WTO has enabled the Commission to play an important role in disputes regarding new trade issues. This fact opened up possibilities for gradual adjustments to article 133 TEC - the core article of the Common Commercial Policy - to incorporate areas such as services, intellectual property and investment. ${ }^{33}$ After the Treaty of Lisbon came into force, article 207 (ex article 133 TEC) read:

The common commercial policy shall be based on uniform principles, particularly with regard to changes in tariff rates, the conclusion of tariff and trade agreements relating to trade in goods and services,

\footnotetext{
29 Bourgeois (n10) 73.

30 Mortensen (n 6) 86.

31 ibid.

32 Anders Ahnlid, 'The European Union and the Launch of the Doha Round' in Ole Elgström and Christer Jönsson (eds), European Union Negotiations: Processes, Networks and Institutions (Routledge 2005) 130-133.

${ }_{33}$ Billiet (n 3) 902.
} 
and the commercial aspects of intellectual property, foreign direct investment, the achievement of uniformity in measures of liberalisation, export policy and measures to protect trade such as those to be taken in the event of dumping or subsidies. The common commercial policy shall be conducted in the context of the principles and objectives of the Union's external action.

The EU considers itself as the most loyal supporter of the WTO. The WTO has widespread membership covering over 150 countries. Therefore, WTO membership is increasingly seen as a necessary recognition by the international community of the reliability of one country's trade policy and a necessary step towards reaping the benefits of international trade. It is therefore not surprising that the number of countries requesting accession to the WTO is increasing and spreading to various areas of the world. Nor is it surprising that countries are ready to undergo lengthy negotiations in order to complete the accession process compared to the time that was requested under GATT. Acceding to the WTO, however, is totally different compared to acceding to the GATT. Whilst the GATT had a rather limited scope, the WTO is an organisation covering almost all facets of international trade and continues to expand. Hence, acceding to the WTO is often compared to 'catching a moving train'. ${ }^{34}$

\section{WTO influence on EC/EU external competences}

No other multilateral treaty has raised so much discussion as the 1994 WTO Treaty concluded as a mixed agreement by the EC and its Member States. The EC (today EU) can use the 'mixed agreements' formula 'when it appears that the subject matter of an agreement or contract falls in part within the competence of the Community and in part within that of the Member States'. ${ }^{35}$

The conclusion of the Uruguay Round led to disagreement between the Commission, on the one hand, and the Council, or most Member States at least, on the other. The dispute was provoked by the issue of the responsibilities of who signs what. The Commission claimed that everything that was covered under the WTO Agreement, including TRIPS, fell under article 133 TEC. ${ }^{36}$ The Common Commercial Policy (CCP) is one of the pillars of the EC/EU external policy and the EC/EU has exclusive competence over issues falling within the scope of article 133 TEC (article 207 TFEU). This puts the Commission in a central position. For this reason, it is not surprising that the Commission was eager at the time of the

\footnotetext{
34 Frid de Vries (n 20).

35 ECJ, Opinion 2/91 (Convention No 170 of the International Labour Organization concerning safety in the use of chemicals at work) [1993] ECR I-1061, para 36.

36 On this issue, see Billiet (n 3) 902-904.
} 
Uruguay Round to have new issues included under the CCP. Most Member States, on the other hand, disagreed with the Commission's broad interpretation of article 133 TEC. Their disapproval was mostly over the Commission's insistence on including trade-related aspects of intellectual property rights and trade in services. According to the Council, these issues fell outside the scope of the CCP and thus outside the scope of the EC's exclusive competence. The solution to this issue was found in the opinion of the European Court of Justice. The procedure for obtaining an opinion from the Court was provided in article 300(6) TEC (article 218(11) TFEU). Eight Member States, including Germany, France and the UK, filed separate briefs to the Court supporting the position of the Council. ${ }^{37}$ According to Billiet, this is a telling sign of how strongly the Member States felt about this issue and of the degree of resistance to the Commission's interpretation. ${ }^{38}$

In its opinion $1 / 94,{ }^{39}$ the Court confirmed that the European Community has exclusive competence with regard to trade in goods and also for cross-border services. Yet it denied the EC exclusive competence over other types of trade in services and for most trade-related aspects of intellectual property rights. The Court concluded that the harmonisation of laws of the Member States on intellectual property rights does not necessarily need to be accompanied by agreements with non-member countries in order to be effective. However, the Court also rejected the view of the Member States that a number of clauses of the TRIPS agreement - those related to judicial remedies - fall within the exclusive competence of the Member States. Therefore, neither the Community nor the Member States have exclusive external competence in relation to TRIPS. It can be said that the Court sided with the Council and the Member States. Its final conclusion was that the EC and the Member States have shared competence to conclude services agreements, except for cross-border services which are covered by article 133 TEC. Therefore, the EC and its Member States are jointly competent for concluding the TRIPS agreement, except for the fight against counterfeit goods which also falls under the CCP. ${ }^{40}$ Since the EC did not have exclusive competence over all the issues involved, the final result was that the WTO charter was signed as a mixed agreement.

According to Bourgeois, Opinion 1/94 could have negative effects on the status of the EC within the WTO. ${ }^{41}$ Billiet argues that such gloominess

\footnotetext{
37 ECJ, Opinion 1/94 (Competence of the Community to conclude international agreements concerning services and the protection of intellectual property) [1994] ECR I-5267.

38 Billiet (n 3) 902.

39 ECJ Opinion (n 37).

40 ibid.

41 See Jacques HJ Bourgeois, 'The EC in the WTO and Advisory Opinion 1/94: An Echternach Procession' (1995) 32 CML Rev 763.
} 
is quite understandable in the light of the events of the mid 1990s. ${ }^{42} \mathrm{Na}-$ mely, the Delors Commission was largely independent of the control of the Member States. For the Member States, especially for France, the Commission went too far when it negotiated the Blair House agreement referring to agricultural issues in November 1992. This agreement between the EC and the US was negotiated by an autonomous Commission. However, the outcome was unacceptable to France. In the end, France gathered enough Member States supporting its position to force the Commission to renegotiate the agreement. Therefore, this act was perceived as a turning point in the delegation of negotiating authority to supranational representatives..$^{43}$ At the same time, the Commission at this stage was not very popular either within the Member States or with general European popular opinion. ${ }^{44}$ Therefore, Opinion 1/94 could not be read as an endorsement for the Commission.

Nonetheless, through the years, the Commission has played an important role within the GATT/WTO and especially in issues connected to TRIPS. Article 133 TEC has also evolved over the years, and today it includes the conclusion of tariff and trade agreements relating to trade in services, the commercial aspects of intellectual property, and foreign direct investments. ${ }^{45}$ The Commission has long argued for incorporating services and intellectual property rights into article 133 TEC. The Member States, as well as the ECJ in Opinion 1/94, strongly opposed this. Nevertheless, the situation has changed substantially since the new WTO dispute settlement system became operational. The strengthened position of the Commission in the WTO dispute settlement system and the Member States' reliance on the Commission in this setting has paved the way for the evolution of article 133 TEC. The WTO's legal approach to dispute settlement influenced the position of the Commission in the internal division of competences within the EC/EU. According to Billiet's alternative explanation of the role of the European Commission within the WTO, the Member States, despite the preferences they might have and the central decision-making role they occupy within the EU, are sometimes overtaken by events on the ground, caused by their reliance on the Commission in the dispute settlement system. This, then, adds to the pressure for a more formal shift in powers to the benefit of the Commission by transforming its de facto gained competences into de jure ones. ${ }^{46}$

\footnotetext{
42 Billiet (n 3) 902-904.

43 ibid.

${ }_{44}$ According to Eurobarometers 33 and 37, the percentage of people with a favorable impression of the Commission was down from 56\% in 1990 to $47 \%$ in $1992<\mathrm{http}$ :// ec.europa.eu/public_opinion/archives/eb/eb33/eb33_en.pdf > and < http://ec.europa.eu/ public_opinion/archives/eb/eb37/eb37_en.pdf> accessed on 30 May 2011.

45 Article 207 TFEU.

46 Billiet (n 3) 916.
} 
This position is strengthened by the fact that the dispute settlement system within the WTO is structured in a way that gives an advantage to the big countries. Therefore, it is the Commission as a representative of the EC/EU that benefits. The position of the Commission is further strengthened by the fact that it possesses the necessary expertise. As a result of the strengthened institutional framework of the WTO, the Commission has been able to gain competences that it otherwise might not have gained. Furthermore, the legalised dispute settlement system within the WTO favours the Commission. It changes the incentives of the Member States to be represented by the Commission and in this way it attributes greater importance to the skills that the Commission possesses. ${ }^{47}$ Therefore, even though the Member States have obviously expressed their preference not to give the EC/EU exclusive competence in the field of TRIPS, the Commission has succeeded in becoming the major European player in the WTO.

\section{The Status of the GATT and the WTO agreements in EU law}

Unlike its position for other international agreements, the ECJ avoided stating that the GATT forms an integral part of Community law. This was mainly due to the fact that the EC was not a contracting party to GATT 1947. However, the ECJ did not use this qualification for the WTO either. ${ }^{48}$ On the other hand, in connection with agreements concluded by the EC/EU with non-Member States, the Court had generally been willing to consider the direct effect of the treaty provisions. ${ }^{49}$ Since the EC had been very active on the international stage, numerous treaties with non-Member States or group of nations were concluded. These Community agreements, just as for all international agreements, did not have automatic direct effect within the domestic legal order of the Member States. However, the Court was willing to enable EC citizens to bring cases based on such agreements before courts within the EC. ${ }^{50}$ Therefore, it seems that the ECJ rulings on the GATT were inconsistent with the judgments on the agreements concluded by the EC with non-Member States. The ECJ held that GATT 1947 needs to be respected by the EC as part of international law. However, there was no obligation to give the GATT direct effect within the Community's legal order. Great flexibility, the lack of reciprocity and permission for unilateral withdrawal were the

\footnotetext{
47 See S Billiet, 'The EC and WTO Dispute Settlement: The Initiation of Trade Disputes by the EC' (2005) 10(2) European Foreign Affairs Review 197; J Heliskosi, 'Joint Competence of the European Community and its Member States and the Dispute Settlement Practice of the World Trade Organization' (1999) 2 Cambridge Yearbook of European Legal Studies 61.

48 See Bourgeois (n 10) 103-108.

49 Case 12/86 Demirel v Stadt Schwäbisch Gmünd [1987] ECR 3719; Case 104/81 Hauptzollamt Mainz v Kupferberg [1982] ECR 3641.

50 Pischel (n 1) 111.
} 
main features of the GATT. Therefore, its provisions were not able to have direct effect within the legal order of the European Community. ${ }^{51}$

The context in which the GATT was perceived within EC law changed considerably after the establishment of the World Trade Organization. This was mainly due to the distinctly developed character of the WTO in relation to the GATT, as well as to the conclusion of a number of agreements within its framework. The issue of the direct effect of WTO agreements was once again at the centre of EU international relations law at the beginning of the 1990s. It was the Council that clearly indicated its unwillingness to attribute direct effect to the WTO agreements. The following is stated in the Preamble of the Council resolution concluding the agreements of the Uruguay Round:

The Agreement establishing the World Trade Organization, including the annexes thereto, is not susceptible to being invoked in Community or Member State courts. ${ }^{52}$

This statement, in political terms, however, is in line with the ECJ's approach. According to the established case law of the ECJ, Member States cannot normally invoke WTO law to invalidate Community law. In cases brought by Member States to review the lawfulness of Community measures, however, the reasons given by the Court are the same as those for which it refuses direct effect, ${ }^{53}$ establishing parallelism in the case law between Member States and private parties, and maintaining it. ${ }^{54}$ However, the Court had held previously that an agreement concluded by the $\mathrm{EC}$ is not inclined to direct application if the parties have ruled out direct effect. The statement of the Preamble has not been agreed upon with the other members of the WTO. As the EC had neither put forward a reservation when signing the Agreement nor put in a provision prohibiting direct effect, the statement in the Preamble as such may not carry much weight when interpreting the Agreement in its context. ${ }^{55}$

According to Pischel, the issue of direct effect of WTO law raises constitutional concerns relating to democratic government, legal certainty, and legal equality. The direct effect of WTO law would increase the need for international legislation, but the WTO system does not have at its dis-

\footnotetext{
51 See Cases 21-24/72 International Fruit Company NV et al $\mathrm{v}$ Produktschap voor Groenten en Fruit [1972] ECR 1219 para 27; Case 70/87 Fediol III [1989] ECR 1805 para 19-20; Case 280/93 Germany v Council (Banana Regulation) (1994) ECR I-4873 para 109.

52 Council Decision 94/800 concerning the conclusion on behalf of the European Community, with regard to matters within its competence, of the agreements reached in the Uruguay Round multilateral negotiations (1986-1994) [1994] OJ L336, 1.

53 Case 300/98 \& Case 392/99 Dior [1998] ECR I-11307 paras 44-45; Case 268/94 Portugal v Council [1999] ECR I-8395.

54 See L Barani, 'Relationship of the EU Legal Order with WTO Law: Studying Judicial Activism' (2009) Garnet Working Paper 70/09, 8-15.

55 See Pischel (n 1) 126.
} 
posal an institution that could serve as legislator. ${ }^{56}$ Pischel argues that the principle of legal equality should also be considered. The EU legal system addresses the concern that EU law might not be applied equally by domestic courts through various mechanisms, above all the preliminary rulings procedure according to article $267 \mathrm{TFEU}$ (article $234 \mathrm{TEC}$ ) ${ }^{57}$ The WTO system, by contrast, does not provide for a similar mechanism to guarantee the equal application of WTO law in domestic courts. Moreover, there is the issue of potential discrimination against domestic producers if WTO law is applied directly. ${ }^{58}$

\section{Conclusion}

The European Union's membership in international organisations is an important issue, because of the major role that international organisations are playing in global and regional cooperation between states nowadays. Global international organisations pose great challenges to the future of the European Union, since they are very often called upon to work out solutions to problems which individual states are no longer able to deal with on their own. The Union's membership in these organisations is crucial for European influence in the world to be emphasised and for global questions, such as free trade, environmental protection, the free flow of telecommunications, technical standards, to be handled firmly.

Furthermore, external relations are of vital importance to the Union and to its future development. The representation and relations of the Union with international organisations and third states depend mainly on the division of powers between the Union and its Member States in the field of external relations. The dynamics of the development of the EU show a progressive extension of its external competences to act in the field of external relations. For these reasons, the article has aimed to present the role that the EC had within the GATT and the role that the EU has within the WTO as one of its original members. It shows how significant the impact of the WTO has been on the development of the EC/EU. The WTO has consistently challenged the Common Agricultural Policy, one of the traditional cornerstones of European integration. In addition, the processes of globalisation have been sponsored by the WTO, in turn influencing the global environment in which the European Union is situated. The very existence of the WTO helps free traders within the European Union strengthen their position against trade protectionists. Finally, depending on the changing configurations of EU domestic power, policies are shaped accordingly.

\footnotetext{
56 ibid.

57 ibid.

58 ibid.
} 